\title{
A study of fall migration of Nearctic- breeding landbirds in central Costa Rica
}

\author{
F. GARY STILES
}

\section{Summary}

In the course of a 13-year study of fall migration of Nearctic-breeding landbirds through a site in the Valle Central of Costa Rica, 5,549 migrant birds of 63 species, and 782 local residents of 28 species, were banded. Arrival dates of migrant species were fairly constant from year to year with passage migrants tending to arrive earlier than winter resident species. Differences in numbers and timing of first-year vs. older birds were noted in some species. Passage migrants showed higher fat deposits than did winter resident species and were virtually never recaptured in succeeding years, indicating a lack of fidelity to specific stopover sites. Winter resident species were recaptured in years following banding at frequencies approaching those for many resident species. Among winter resident species, individuals arriving early had higher fat deposits and were recaptured less frequently than those arriving later; apparently the latter were most likely to remain for the winter in or near the study area. This arrangement probably reduces intraspecific competition between transient and resident individuals of these species. Both at regional and local levels, migrant and local resident species differed in size distributions and to some extent in diet; these differences may reduce competition between these groups. Resident species had generally ceased to nest by the time the migrants arrived in large numbers, but usually were feeding fledglings and/or moulting, suggesting that the presence of the migrants does not result in a scarcity of resources. The long-term but low-intensity, low-budget nature of this study may make it feasible to duplicate in many areas of the Neotropics, where information is needed regarding effects of land-use changes on resident and migrant avifaunas.

A lo largo de los 13 años de un estudio de la migración otoñal de las aves que anidan en el neártico a través de una localidad en el Valle Central de Costa Rica, se anillaron 5.549 aves migratorias de 63 especies, y 782 residentes locales de 28 especies. Las fechas de llegada de las especies migratorias fueron bastante consistentes de año a año, con las migratorias de paso llegando generalmente antes que los residentes invernales. En algunas especies, se registraron diferencias en números o épocas de migración entre adultos e inmaturos. Las especies de migratorios de paso mostraron mayores reservas de grasa que los residentes invernales, y casi nunca fueron recapturados en años posteriores, lo que indica que individuos de estas especies no muestran fidelidad a sitios de escala específicos en sus migraciones. Individuos de las especies de residentes invernales 
fueron recapturados con frecuencia no mucho menor que la de los residentes locales. Entre los residentes invernales, los individuos que llegaron más temprano tenían más grasa y fueron recapturados menos frecuentemente en años posteriores que los que llegaron más tarde al área. Estos últimos individuos son evidentemente los que se quedan más frecuentemente; este arreglo tiende a disminuir la competencia entre individuos transeúntes y residentes de estas especies. Tanto a nivel local como a nivel regional, especies migratorias y residentes locales presentaron diferencias marcadas en las distribuciones de tamaño $y$, hasta cierto punto, en dieta. Tales diferencias podrían reducir la competencia entre los dos grupos. Aunque los residentes generalmente habían terminado de anidar cuando llegaban la mayoría de los migratorios, todavía estaban alimentando a sus pollos o volantones, y/o mudando el plumaje: esto sugiere que la llegada de los migratorios no les produjo una escasez marcada de recursos. Estudios de este tipo, a largo plazo pero de baja intensidad y con un presupuesto mínimo, pueden ser factibles en muchas áreas del neotrópico, en donde hacen mucha falta datos básicos sobre la migración, y sobre los efectos de los cambios en el uso de la tierra sobre las poblaciones de aves, tanto residentes como migratorias.

\section{Introduction}

The phenomenon of bird migration in the Neotropics has received increasing study in recent years. This is not only because a large proportion of the breeding avifauna of North America migrates to the tropics, but also because migratory behaviour and pronounced seasonal movements have been found to characterize many Neotropical "resident" birds as well (e.g. Rosselli this issue). In fact, the two types of migration may be causally, ecologically and evolutionarily related: the differences between long-distance, latitudinal migrations and shorter intratropical movements may be quantitative rather than qualitative (Levey and Stiles this issue). All such movements are ultimately related to seasonal variations in resources and habitat characteristics, and all share the ecological feature of adding transient or seasonally resident individuals to communities of sedentary birds for varying periods. From the conservation viewpoint, all of these movement types have in common that they require us to think on a larger geographic scale when considering critical resources or habitats for migratory birds.

Thus, the minimum required habitat for a tropical hummingbird may be an entire watershed; for a large cotinga, an elevation range of $2,000 \mathrm{~m}$ or more of forested mountain slopes; or for a Blackburnian Warbler Dendroica fusca, a boreal forest in Maine, an oak forest in Colombia, and appropriate stopover sites in between.

In trying to design intelligent conservation strategies for migratory birds, we are often hampered by a lack of information, for part or all of a species's migratory trajectory. For altitudinal intratropical migrants, we often lack data on the regularity of such movements, the proportion of the population that migrates, and the importance of fluctuating resources in determining the extent of the migration - themes that are treated by various authors in this volume. For long-distance, latitudinal migrants, our information on the tropical segment of 
their migration routes, and on their ecological interactions with more sedentary bird populations on the "wintering" grounds, is often sketchy. Particularly lacking are long-term studies of migration at particular sites in the Neotropics, where even the most basic questions have been at best only partially answered: which species pass through, which stay? How constant are numbers and timing of the different migrants from year to year? What are the correlates of transient vs. resident status at a site? Do different sex/age groups show similar or different patterns of migration? How do transient, seasonal and permanent residents compare with respect to such parameters as mass, morphology, habitat and resource use? How do these groups interact?

My purpose in introducing this issue is not to review what is known regarding these questions - excellent summaries of existing knowledge can be found in Keast and Morton (1980), Rappole et al. (1983), several symposia in Ouellet (1988) and in the various contributions in this issue. Rather, I wish to demonstrate how perennially time-limited, short-staffed, and under-funded ornithologists resident in the Neotropics might go about answering them, using the results of a long-term, low-intensity study I conducted in Costa Rica.

At this point I should emphasize that conditions for the practice of ornithology are very different in most developing countries than in the North Temperate Zone. Occupations for professional ornithologists as such are few, limited to a small number of universities or museums, usually located in major cities.

Budgets for fieldwork are limited at best, and most time must be devoted to teaching, administrative and/or curatorial duties. For most Neotropical countries, the number of trained ornithologists can be counted on the fingers (or thumbs) of one hand, and the burgeoning cadre of birdwatchers and volunteer banders so characteristic of the U.S.A. and northern Europe is conspicuously absent. This lack of amateur, "grass-roots" ornithology is a result of cultural and economic processes common to many of the developing countries. The concentration of ornithological knowledge in a few museums and universities, the size and complexity of the avifauna, the lack of educational materials and field guides in local languages and of basic equipment like binoculars, the scarcity of leisure time for most people (especially in rural areas) and the lack of education in conservation values and natural history among the governing class, are all contributing factors. Government economic priorities revolve around feeding, healing and housing a runaway population cutting an ever-widening swath in natural habitats, and in attempting to combat the results (but rarely the causes) of such environmental degradation. Under these conditions, the development of large-scale bird-banding programmes requiring much infrastructure and widespread volunteer participation seems impossible in the short run. Only now, in a few countries such as Brazil, are organized banding programmes getting started, and these are largely dependent upon international financing. With the improving availability of such funding through programmes like "Partners in Flight", the limiting factor is increasingly the number of trained workers with time to devote to reasonably systematic banding.

Therefore, I propose to devote the rest of this paper to describing a type of study that I feel can be rather easily duplicated in many areas, since it involves a minimal amount of personnel and equipment and a rather small but welldistributed expenditure of time and effort. This study was carried out at a site 
in the Valle Central of Costa Rica during the fall migration period of Nearcticbreeding birds, over a span of 13 years (1976-1988). The accumulated data provide at least partial answers to many of the above questions.

\section{Methods}

Arrival dates of migrants were determined by visual observations by myself, my students and colleagues in the course of birdwatching walks in and around the Universidad de Costa Rica (hereafter UCR) campus and surrounding areas; in casual observations while walking about the campus, or between the campus and lodgings; or in the course of banding operations. We noted both the first appearance of a species during the fall migration period (roughly late July or early August through November), and the first major migratory wave.

Banding operations were conducted in $\mathbf{a} 0.5$ ha area of second-growth scrub on an abandoned coffee finca $0.5 \mathrm{~km}$ north-east of the UCR campus $\mathrm{c} .8 \mathrm{~km}$ east of the centre of San José, at an elevation of $1,200 \mathrm{~m}$ (Figure 1 ). This finca was purchased by UCR around 1970 for future development, but was allowed to revert to secondary succession thereafter. Parts of the 8 ha area were developed during the 1970s but our banding area remained moderately intact until 1990. At the time of purchase, this area was probably a scrubby pasture; a small aqueduct extended along one edge of the area. In the succeeding years, parts of the area supported a low (2-4 m) scrubby woodland dominated by Acacia angustissima (Mimosaceae) and Acnistus arborescens (Solanaceae) trees with scattered trees of other species, notably Trema micrantha (Tiliaceae) and Calliandra sp. (Mimosaceae) (Figure 2). Other parts of the area were invaded by dense stands of "guinea" grass Panicum maximum. Because of firewood-gathering and burning during the dry season (usually January through March, following the observation periods) by residents of the adjoining barrios, the vegetation of the area retained its low, scrubby character throughout the study period. Banding operations were conducted 1-3 times weekly between mid-September and late November or early December of each year. At the start of each banding season, net poles were cut and holes were made for the poles to facilitate setting mistnets rapidly. During a netting operation we arrived on the area before dawn (c. $04 \mathrm{~h} 30-04 \mathrm{~h} 45$ ), and set $c .15$ nets each $12 \mathrm{~m}$ in length. The same number and arrangement of nets was used throughout a netting season, except for 1976, the first year, when fewer nets were used and the arrangement was less standard-

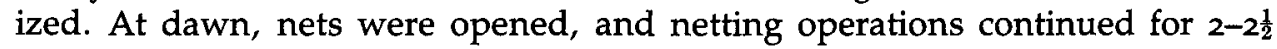
hours. By $08 \mathrm{~h} 30$ we were closing and removing nets, and were usually able to arrive on campus in time for a (badly needed) cup of coffee before nine o'clock classes!

Each migrant captured was sexed and aged from plumage characters and skull ossification, insofar as possible. Characters used in sex/age determination were taken from standard published sources like Robbins (1964) and Wood (1969), or were developed by me in the course of collecting and museum studies; species determination was facilitated in difficult groups by the keys in Phillips $e t$ al. (1966) for Contopus and Empidonax, and Lanyon and Bull (1967) for Oporornis.

Each migrant was scored for subcutaneous fat deposits on a scale running from o (no fat) to 5 (heavy deposits over most body areas); wing and tail measurements were taken to the nearest $0.5 \mathrm{~mm}$ with a millimetre ruler; and birds 


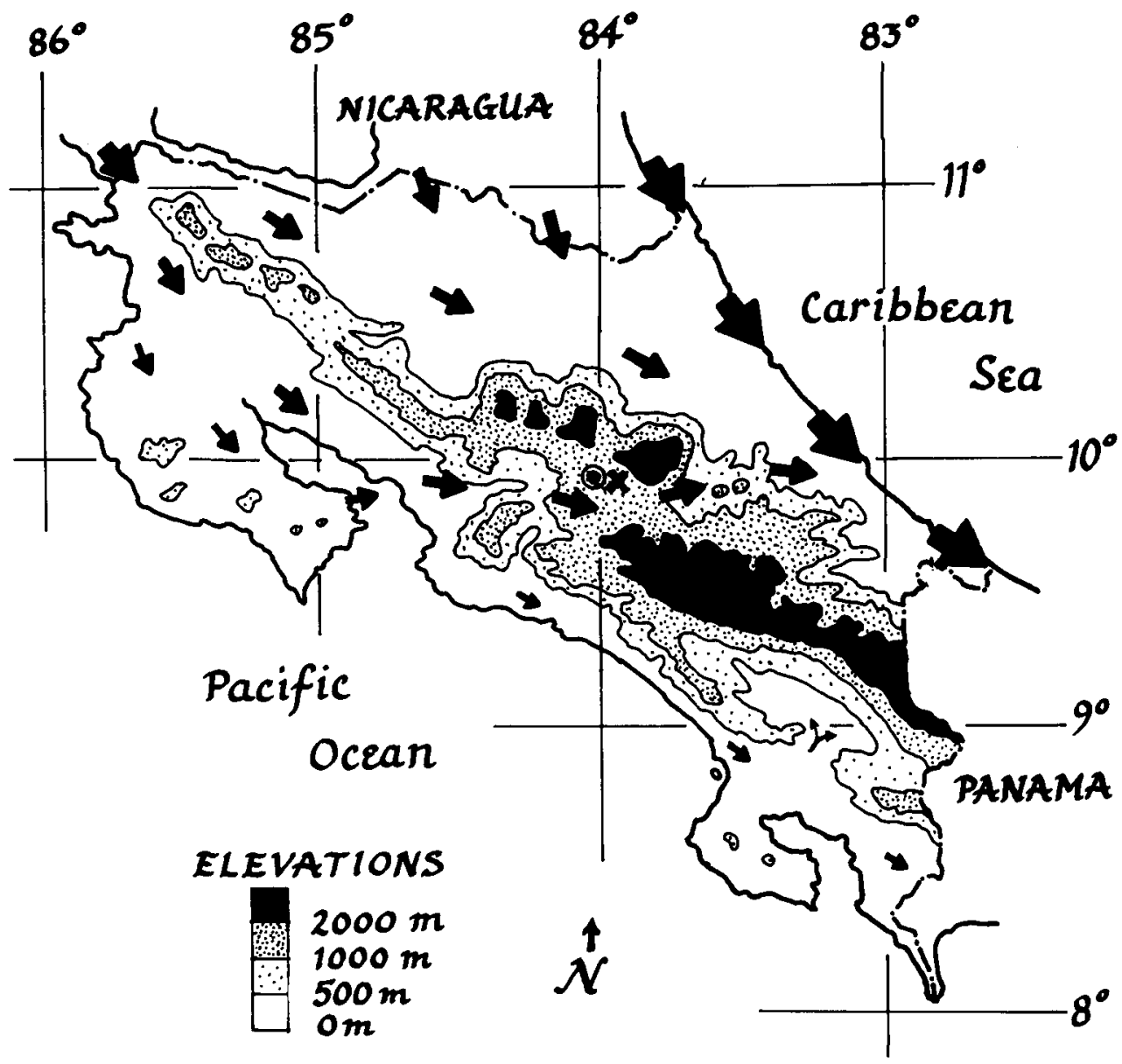

Figure 1. Location of the study area $(x)$ in relation to the city of San Jose (circle), major mountains, and the approximate volume and direction of fall landbird migration in Costa Rica. Note that migration in the Central Valley, which includes the study area, proceeds from west-north-west to east-south-east.

were weighed to the nearest $0.1 \mathrm{~g}$ with a Pesola spring balance. All migrants were banded with U.S. Fish and Wildlife Service bands and released.

From 1980 onward, all local residents captured were colour-banded with numbered plastic bands (manufactured by A. C. Hughes), except for Zonotrichia capensis and Turdus grayi (English names of species mentioned in this paper are in Appendices 1 and 2), which were so numerous that banding them would have resulted in bankruptcy! In addition to the above data, for local residents we also took data on breeding status (presence of brood-patch or enlarged cloacal protuberance) and moult.

\section{Results}

Over the 13 years, we averaged 18 banding sessions and c.60o net-hours per season. We banded a total of 5,549 migrants of 63 species in 12 families 


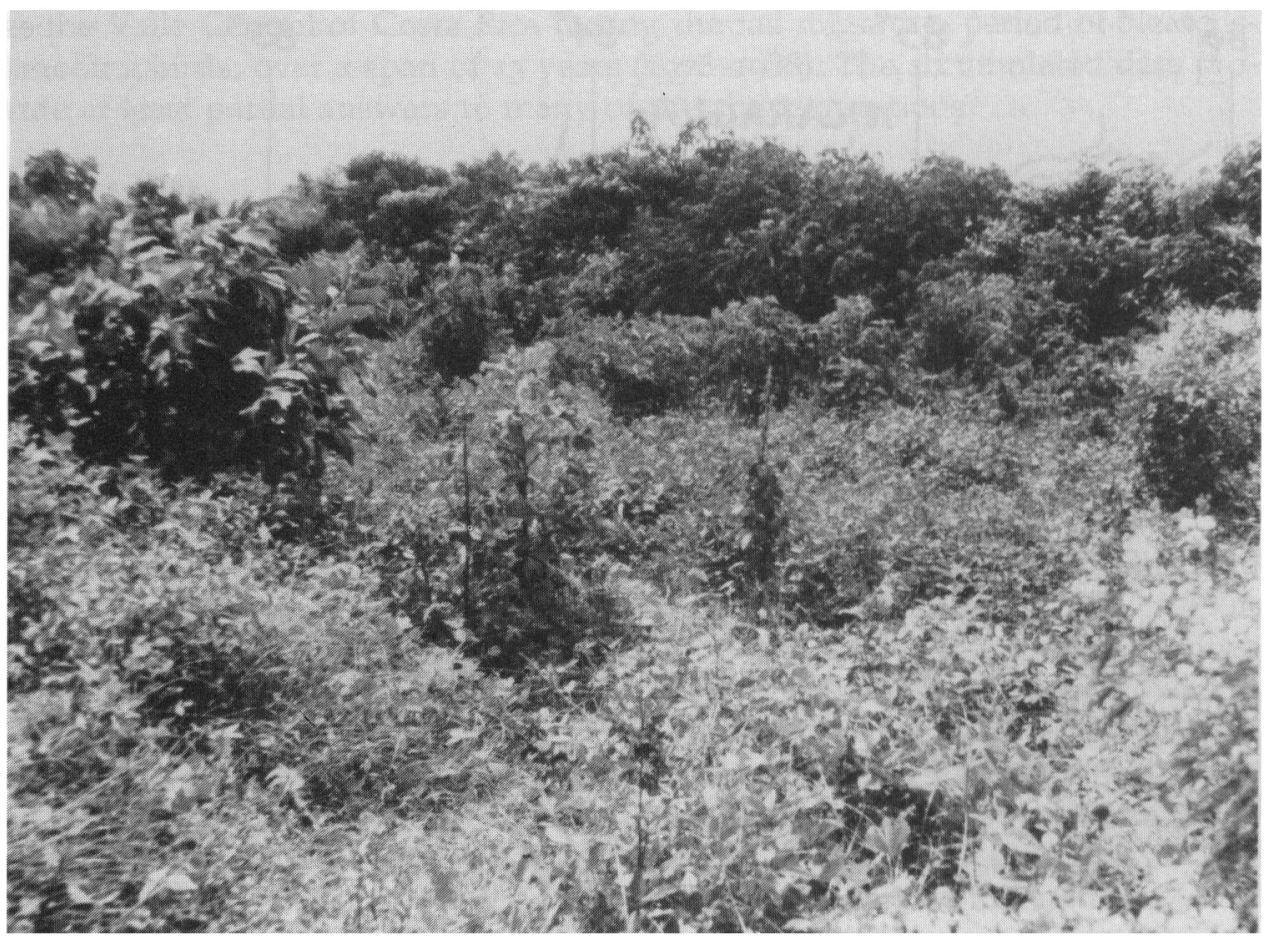

Figure 2. Vegetation of the study area, December 1982. A net lane passes through the taller (2-3 m) Acacia angustissima scrub at rear. The study area retained this scrubby character throughout the study period due to burning and firewood-gathering each dry season, in the months following the fall banding season.

(Appendix 1). Families best represented were Parulidae (25 species), Tyrannidae (10), Emberizidae (6), and Vireonidae (4); species most captured were Vermivora peregrina (897), Empidonax alnorum (606), Passerina cyanea (525), Vireo olivaceus (447), Catharus ustulatus (351), Oporornis philadelphia (337), and Empidonax trailli (251). Between 1980 and 1988, we colour-banded 782 local residents of 28 species in 15 families. A complete list of species in the general area of the UCR campus is given by Stiles (1990).

I assigned to each migrant species a status in the study area based primarily on extensive field experience throughout Costa Rica (see Stiles and Skutch 1989) and on published sources, principally Ridgely (1981), AOU (1983), and Hilty and Brown (1986). These categories were: P1, passage migrant to Panama or South America (16-18 species); P2, passage migrant to other areas in Costa Rica (9-10); RV, winter residents in central Costa Rica, but rarely or never on the study area (7 or 8$)$; RR, regular winter resident on the study area (15); XV, accidental visitor or transient, not seen or captured more than once or twice per season (10); and XR, accidental resident - two species recorded very rarely, but which, if they arrived at all, were fairly likely to remain for several months.

The uncertainty in some of these numbers reflects the fact that a number of species presented "dual status" and were difficult to classify unequivocally in the above scheme. For instance, Dendroica petechia wintered regularly on the 
study area in small numbers, more commonly in the lowlands of both slopes in Costa Rica, and abundantly in northern Colombia (pers. obs.); thus most individuals captured were undoubtedly transients. Similarly, $D$. fusca winters very rarely in the Valle Central, more regularly in montane forests in Costa Rica (cf. Stiles and Skutch 1989), and abundantly in the Colombian Andes (pers. obs.). The " $\mathrm{P}_{2}$ " species included mainly birds that wintered in the Caribbean lowlands. Through visual observations on diurnal migrants (e.g. kingbirds, swallows) and occasional moon watches (cf. Lowery and Newman 1966), I found that the predominant direction of fall migratory movements in the Valle Central was west-north-west to east-south-east (Figure 1).

In the following section, presentation of results will be organized around specific questions, and the data that help answer them.

\section{When do migrants arrive? How variable are arrival dates?}

To facilitate statistical analysis, I numbered days sequentially starting with 1 August; thus 1 September is day 32, 15 October day 76 , etc. The first migrants to arrive were, on average, Icterus spurius (day 28), Setophaga ruticilla (day 30), and Contopus sordidulus/virens and Empidonax alnorum/ trailli (individuals of these species-pairs are too similar in appearance in fall to identify safely to species, and usually were not calling). Most migrants arrived between mid-September and mid-October; consistently late in arriving were Hylocichla mustelina (81) and Vireo philadelphicus (90); see Appendix 1 for details. In species with 10 or more reasonably reliable arrival dates, the range is usually not more than 15-20 days, the standard deviation generally 5-10 days. Arrival dates tended to vary more between years among rare and/or inconspicuous species, as might be expected: thus the standard deviation for Hylocichla mustelina (12) was nearly twice that for Catharus ustulatus (7). In comparing passage migrants with winter residents, no difference in variability of arrival dates was found (respective mean standard deviations 7.25 and $7.15 ; t=0.21, p>0.50$ ). However, arrival dates for passage migrants tended to be earlier than for winter residents (Mann-Whitney $U=$ $65.5, \mathrm{p}<0.05)$.

Do different age groups pass through in different numbers, and at different times?

For most species, the numbers of adults vs. immatures banded showed no significant differences ( $\chi^{2}$ tests). However, in Myiarchus crinitus, Catharus ustulatus and Vireo philadelphicus, adults significantly exceeded immatures; the reverse was true for Empidonax alnorum and trailli; Vireo olivaceus and flavoviridis; Dendroica fusca, petechia, and pensylvanica; Vermivora chrysoptera; Wilsonia canadensis and pusilla; and Passerina cyanea (Table $\mathrm{x}$ ). Among winter residents, adults equalled or exceeded immatures banded in a slight majority of species, while the reverse was true for passage migrants; however, this difference was not statistically significant $\left(\chi^{2}=1.06, p>0.25,1 \mathrm{df}\right)$.

Similarly, the proportion of adults vs. immatures banded through the migration period did not vary significantly in most species (Kolmogorov-Smirnov two-sample tests, adults vs. immatures banded per two-week period). Exceptions included Empidonax alnorum and trailli, Contopus virens and sordidulus, Vireo 
Table 1. Numbers of adults vs. immatures (AHY vs. HY) ${ }^{1}$ of different species banded on study area, $1976-1988$

\begin{tabular}{lrr}
\hline Species & $\begin{array}{c}\text { No. adults } \\
\text { banded }\end{array}$ & $\begin{array}{c}\text { No. immatures } \\
\text { banded }\end{array}$ \\
\hline${\text { Species in which adults exceeded } \text { immatures }^{2} \text { : }}_{\text {Myiarchus crinitus }}$ & \\
Catharus ustulatus & 50 & 18 \\
Vireo philadelphicus & 194 & 106 \\
Species in which numbers of adults and immatures did not differ & 28 & 14 \\
significantly & & \\
Empidonax virescens & & \\
Contopus virens & 18 & 17 \\
Contopus sordidulus & 49 & 64 \\
Vermivora peregrina & 52 & 63 \\
Dendroica castanea & 441 & 401 \\
Seiurus aurocapillus & 23 & 22 \\
S. noveboracensis & 48 & 53 \\
Piranga rubra & 58 & 56 \\
Pheucticus ludovicianus & 19 & 22 \\
Species in which immatures exceeded adults ${ }^{2}$ & 40 & 33 \\
Empidonax alnorum & & \\
E. trailli & 149 & 344 \\
Vireo olivaceus & 88 & 122 \\
V. flavoviridis & 148 & 235 \\
Vermivora chrysoptera & 17 & 50 \\
Dendroica petechia & 15 & 29 \\
D. fusca & 40 & 89 \\
D. pensylvanica & 59 & 94 \\
Wilsonia pusilla & 38 & 87 \\
W. canadensis & 38 & 97 \\
Passerina cyanea & 59 & 103 \\
\hline Exluding individua & 173 & 269 \\
\hline
\end{tabular}

${ }^{1}$ Excluding individuals of indeterminate age (AHY, After Hatching Year, i.e. second year or older; HY, Hatching Year, i.e. first year).

${ }^{2}$ Differences evaluated by chi-square tests ( $1 d f$ with Yates correction).

olivaceus, and Oporornis philadelphia, in all of which adults tended to pass through earlier than immatures (Figure 3); in no species did immatures tend to precede adults.

Do passage migrants and winter resident species differ in the amount of fat deposits?

Fat scores tended to be highly variable within all species, at any given time. For instance, when a major migratory wave was present on the study area and many individuals of a given species were captured in a banding session, the individuals typically ran the gamut of fat scores from very little or none (0-1) to moderate to heavy fat reserves $(3-5)$. Moreover, there was considerable variation between years in mean fat reserves of a species for any given two-week period in the migration season. Nevertheless, certain average differences between winter residents and passage migrants were evident.

Mean fat scores for passage migrants were, on the whole, higher than for winter residents (Table 2, Mann-Whitney $U=40, p<0.05$ ). However, some species were exceptional in this regard. The two Contopus species, although 


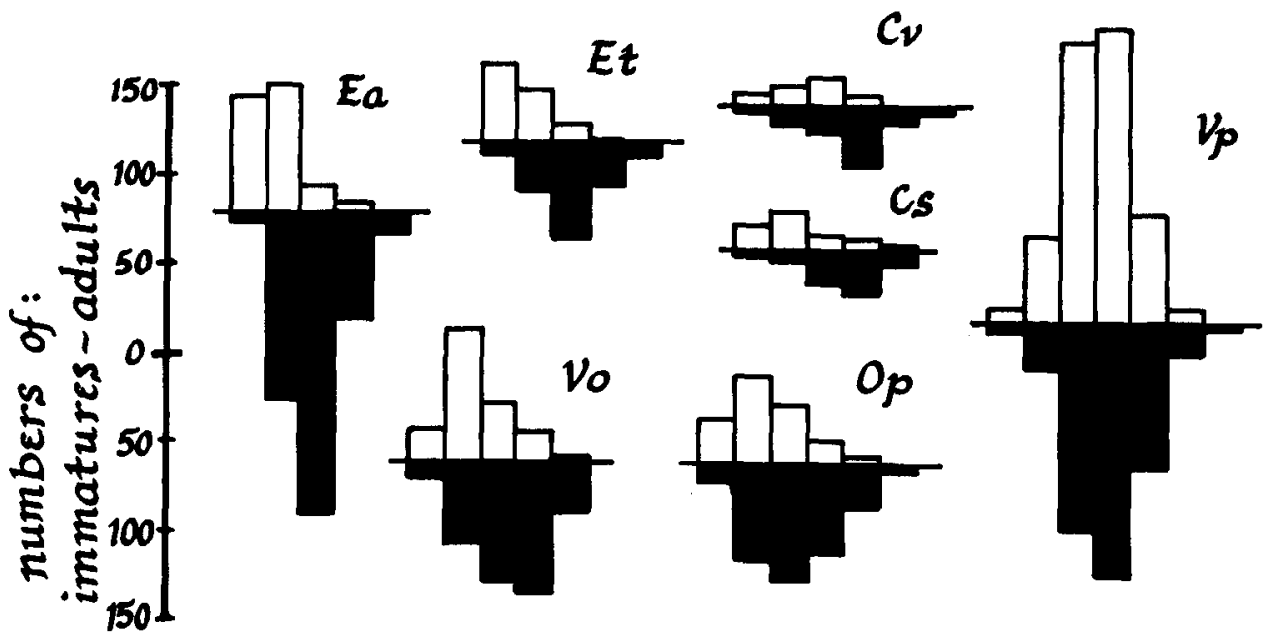

Figure 3. Changes in numbers and proportions of adults (AHY) and immatures (HY) banded during successive two-week periods during the 13 years of the study. Six species showed a significant tendency for adults to precede immatures (Kolmogorov-Smirnov two-sample tests): Empidonax alnorum (Ea), E. trailli (Et), Contopus virens ( $\mathrm{CV}), \mathrm{C}$. sordidulus (Cs), Vireo olivaceus (Vo) and Oporornis philadelphia $(\mathrm{Op})$. The same tendency is shown weakly by the species most captured, Vermivora peregrina (Vp).

Table 2. Mean fat scores of winter resident (RR) vs. passage migrants (P1) species banded on UCR Finca study area, $1976-1988$

\begin{tabular}{lclc}
\hline $\begin{array}{l}\text { Passage migrants } \\
\text { species }\end{array}$ & $\begin{array}{c}\text { Mean fat } \\
\text { score }\end{array}$ & $\begin{array}{l}\text { Winter residents } \\
\text { species }\end{array}$ & $\begin{array}{c}\text { Mean fat } \\
\text { score }\end{array}$ \\
\hline Empidonax alnorum & 1.42 & Myiarchus crinitus & 1.26 \\
E. trailli & 1.50 & Vireo philadelphicus & 1.16 \\
Contopus virens & 1.16 & V. flavifrons & 1.30 \\
C. sordidulus & 0.95 & Vermivora peregrina & 1.23 \\
Catharus ustulatus & 1.95 & Dendroica petechia & 1.95 \\
C. minimus & 1.68 & D. pensylvanica & 0.97 \\
Vireo olivaceus & 1.72 & Seiurus auracapillus & 1.19 \\
V. flavoviridis & 2.21 & S. noveboracensis & 1.45 \\
Dendroica castanea & 1.45 & Oporornis philadelphia & 1.16 \\
D. fusca & 1.34 & Wilsonia pusilla & 1.08 \\
Wilsonia canadensis & 1.54 & Icterus galbula & 1.22 \\
Piranga olivacea & 1.88 & Piranga rubra & 0.95 \\
& & Pheucticus ludovicianus & 1.56 \\
& & Passerina cyanea & 1.06 \\
\hline
\end{tabular}

undoubted passage migrants, consistently had very low fat reserves. Another case in point was Dendroica petechia: although classified as a winter resident, its mean fat score was quite high, much more in line with the passage migrants.

Here, the problem may relate to the species's "dual status" on the area. Typically, large numbers of $D$. petechia with high fat reserves were captured in September; by October, the number of individuals captured was much lower, 


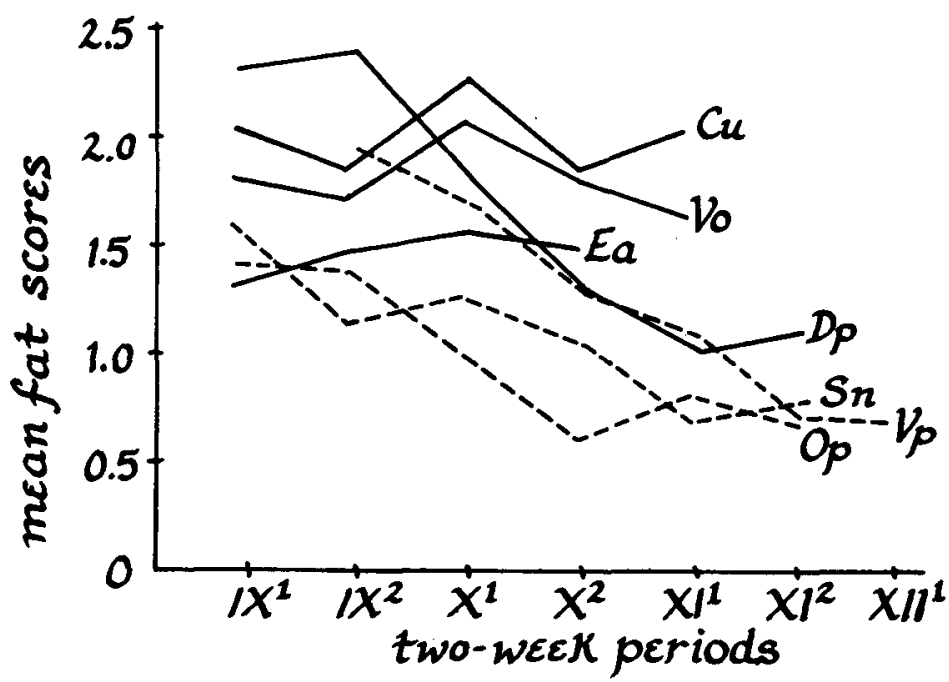

Figure 4. Mean fat scores, by two-week periods, for several passage migrants (solid lines) and winter residents (broken lines) on the study area. Note that in the former fat reserves fluctuate but generally remain high through the fall, whereas in the latter they tend to decline from moderate to low levels. Fat scores of Dendroica petechia are very high early in the fall, when the species is a passage migrant, but fairly low in late arrivals, which may in fact be winter residents. Abbreviations for species as in Figure 3, also Dp, Dendroica petechia; $\mathrm{Cu}$, Catharus ustulatus; and $\mathrm{Sn}$, Seiurus noveboracensis.

and most had low fat reserves (Figure 4). This suggests that the first, large waves of $D$. petechia were in fact passage migrants, as suggested by the species's winter distribution (see above); the much smaller number of winter residents apparently were among the late arrivals to the study area.

Such a pattern may be fairly general among winter resident species. Among those species in which individuals continued to arrive on the area over a period of two months or more, there was a general tendency for early-arriving individuals to have higher fat reserves than individuals first banded late in the season (Figure 4).

This suggests that among species that were winter residents on the study area, the early-arriving individuals included mostly birds that would continue on to other areas; evidently it was mainly the late arrivals that settled down to winter on or near the study area. This pattern will be analysed further below, with respect to data on recaptures. By contrast, for species that were strictly passage migrants through the area, fat levels fluctuated but showed no strong tendency to decline through the migratory period (Figure 4).

Do passage migrants and winter residents return to the banding area in similar frequencies in succeeding years?

An average of $6 \%$ of all banded individuals of winter resident species were recaptured on the study area in one or more years following banding. An indication of the site-fidelity of some of these individuals is the fact that they were recaptured in several successive years. Among the species with most recaptures, 
Table 3. Numbers of individuals recaptured among totals banded through 1987 of winter resident and passage migrant species

\begin{tabular}{lcc}
\hline Status & $\begin{array}{c}\text { Total number } \\
\text { banded }\end{array}$ & $\begin{array}{c}\text { Number of } \\
\text { individuals } \\
\text { recaptured }\end{array}$ \\
\hline Passage migrants to South America (P1) & $\mathbf{1 , 9 2 7}$ & 0 \\
Winter residents in Costa Rica but not in study area (P2, RV) & 611 & 2 \\
Winter residents in/near study area (RR) & 2,569 & 151 \\
\hline
\end{tabular}

at least one individual was recaptured in five consecutive years in Oporornis philadelphia, four years in Wilsonia pusilla and Vermivora peregrina, and three years in Passerina cyanea and Seiurus aurocapillus. By contrast, not a single individual of any passage migrant species (P1), of nearly 2,000 banded, was ever recaptured. Among species known to winter in Costa Rica but not in the Valle Central (at least regularly), no individual was ever recaptured. Among species that wintered in the Valle Central but not on the study area, recaptures were much less frequent, on the order of $0-3 \%$. These were mainly species that preferred more wooded habitats (e.g. Oporornis formosus, Vermivora chrysoptera). These differences are statistically significant: for $P_{1}$ vs. $R R, \chi^{2}=116.4, p<0.001$; for $P_{2} / R V$ vs. RR, $\chi^{2}=36.9, \mathrm{p}<0.001 ; 1 \mathrm{df}$ (Table 3). These results indicate that passage migrants through the Valle Central of Costa Rica do not show site-fidelity for stopover areas, unlike the situation in many shorebirds, for instance. An especially intriguing case that proves the point is one Coccyzus americanus that, almost exactly one year after being banded on the study area, flew into a plate-glass window in downtown San José c. $9 \mathrm{~km}$ west of the study area (ironically, at the U.S. Embassy!). Such birds may thus continue to use the same general migration route, but not specific stopover sites, in succeeding years.

Using frequency of recapture as an indicator of passage migrant vs. winter resident status, we can now return to the question of whether, within winter resident species, early- or late-arriving individuals are more likely to remain. In each of the seven species most recaptured, the proportion of recaptures was higher for individuals banded late in the season than for those banded early. Moreover, in six of these seven species, early-banded individuals had higher mean fat deposits than those first banded late in the season (Table 4). Both of these points reinforce the idea that it is the late arrivals among these species that are most likely to settle in or near the area as winter residents, whereas early arrivals tend to continue on. The one exception in terms of fat deposits was Passerina cyanea, which was also exceptional in terms of its type of winter resident status.

Instead of establishing a winter territory like most other species (cf. Stiles and Skutch 1989), $P$. cyanea is nomadic in winter in central Costa Rica, moving about between areas with abundant crops of grass seeds. On the study area, groups or flocks of $P$. cyanea remained on the area only so long as "guinea" grass Panicum maximum seeds were abundant, usually into late December or January.

How do recapture rates of permanent and winter residents compare?

Among the $\mathbf{2 8}$ species of permanent resident species banded on the study area, recapture rates in years following banding varied from o to c. $30 \%$, with a mean 
Table 4. Frequency of recaptures in succeeding years, and mean fat scores, of winter resident species captured early and late in their respective migratory seasons

Species

Proportion of individuals recaptured in succeeding years that were banded

\begin{tabular}{llc}
\hline & Early & Late \\
\hline Vermivora peregrina & 0.055 & 0.091 \\
Dendroica petechia & 0.000 & 0.065 \\
Seiurus aurocapillus & 0.117 & 0.222 \\
S. noveboracensis & 0.051 & 0.069 \\
Oporornis philadelphia & 0.023 & 0.133 \\
Wilsonia pusilla & 0.062 & 0.255 \\
Passerina cyanea & 0.037 & 0.111
\end{tabular}

Mean fat scores of individuals that were:

\begin{tabular}{ccccc}
\hline $\begin{array}{c}\text { banded early } \\
\text { in season }\end{array}$ & $\begin{array}{c}\text { banded late } \\
\text { in season }\end{array}$ & & $\begin{array}{c}\text { recaptured in } \\
\text { succeeding years }\end{array}$ & $\begin{array}{c}\text { not } \\
\text { recaptured }\end{array}$ \\
\cline { 1 - 1 } \cline { 5 - 5 } 1.53 & 0.79 & & 0.94 & 1.25 \\
1.91 & 1.17 & & 1.00 & 1.96 \\
1.16 & 1.28 & & 1.09 & 1.20 \\
1.28 & 0.87 & & 1.14 & 1.47 \\
1.30 & 0.75 & & 1.06 & 1.17 \\
1.10 & 0.94 & & 1.00 & 1.09 \\
1.02 & 1.08 & & 1.24 & 1.05 \\
\hline
\end{tabular}

of $19.8 \%$ (Appendix 2). For many, recapture rates did not differ greatly from those of winter residents, particularly if only mean recapture rates of latearriving individuals of the latter are considered (see Table 4). Species that regularly nested in the study area (e.g. Thryothorus modestus, Atlapetes gutturalis, Catharus aurantiirostris, Melozone biarcuatum) tended also to be recaptured most regularly; some individuals were recaptured in several successive years (up to eight in C. aurantiirostris, six in T. modestus, and five in $A$. gutturalis, for instance). Species nesting in the area but then departing until the next nesting season, like Volatinia jacarina (which like $P$. cyanea was largely dependent upon seeds of "guinea" grass), were recaptured rather less frequently. Other species that regularly foraged in the study area but usually nested in other habitats or in nearby areas (e.g. Amazilia spp., Notiochelidon cyanoleuca, Troglodytes aedon) were recaptured to varying degrees, but generally not in many successive years (e.g. only one of $18 \mathrm{~A}$. tzacatl was recaptured in three different years). Some species were captured and/or recaptured in low frequencies because they preferred taller vegetation or usually flew and perched at levels higher than the nets (e.g. Pitangus sulphuratus, Megarhynchus pitangua, Tyrannus melancholicus, Piaya cayana). This latter situation was duplicated in certain passage migrants (e.g. Tyrannus tyrannus) and winter residents (e.g Icterus galbula) that were captured and/or recaptured less frequently than might have been expected given their regular presence in and around the study area.

How do permanent resident and migrant species compare in ecology and morphology?

The question of how migrant and permanent residents interact has been debated frequently in avian ecology (see, e.g., contributions and citations in 
Keast and Morton 1980, Rappole et al. 1983 and Ouellet 1988). Whether migrants are "peripheral" to, or complementary to, resident bird communities is important in understanding the dynamics and evolution of migration; several contributions to this symposium also directly or indirectly address this question, to which, although the issue was not central to the present study, some of the data gathered here are pertinent. For these purposes, weight (mass) was considered an adequate indicator of size, and species were assigned to weight classes on an approximately logarithmic scale; weights were taken from my unpublished data (summarized in general terms in Stiles and Skutch 1989). Species were next assigned to diet categories as in Stiles (1983); diet data were taken from Stiles and Skutch (1989).

First, comparing only the species of local residents and winter residents (RR, $R V$, and $X R$ categories: see above) captured on the study area, significant differences were found in both size distributions (Kolmogorov-Smirnov 2-sample test, $\left.D_{\max }=0.45, p<0.05\right)$ and distribution of species in diet categories $\left(\chi^{2}=14.6\right.$, $\mathrm{p}<0.01,2 \mathrm{df}$, combining nectar-fruit-seeds and large insect-vertebrate categories). Winter residents were smaller than permanent residents (modal weight categories 6-12 $\mathrm{g}$ and $13-25 \mathrm{~g}$ vs. 26-50 $\mathrm{g}$ and 51-100 $\mathrm{g}$ ), and the vast majority of species consumed small insects, whereas local residents showed a much greater dietary diversity (Table 5).

A more representative comparison might be effected using the entire assemblage of migratory birds of all categories passing through the UCR area, and the entire spectrum of local resident species. Such a comparison would include both local and migrant species not present, or at least not captured, on the 0.5 ha study area (e.g. high-flying species, those larger than c. 150-200 g, and those preferring other habitats) and passage migrants that, because of their abundance - albeit for short periods - might have a significant ecological impact. A detailed list of local residents and migrants, with their status in the UCR area, was presented by Stiles (1990). Excluding very rare and accidental species, a sample size of 94 local residents and 66 migrant species may be used. Diet and weight data for all species are available in Stiles and Skutch (1989). Interestingly, the results of such a broad-based comparison were precisely the same as for the more restricted set of species captured on the study area. Significant differences in weight distributions between resident and migrant species were found $\left(D_{\max }=0.35, p<0.01\right)$ and in the distribution of species in diet categories $\left(\chi^{2}=\right.$ 13.9, $\mathrm{p}<0.05,3 d f$. As in the former case, local residents average larger. Fully two-thirds of the migrants take small insects as their principal or exclusive food, whereas less than $40 \%$ of local residents do; more local residents take large insects, fruits, seeds and nectar than do migrants (Table 5).

These comparisons suggest that, at both very local and regional levels, migrants may complement local residents in size and to some extent in diet. Given that during large migratory waves, 50-75 or more migrants were often captured during a single banding session, it is evident that at such times the total avian biomass of the study area was undoubtedly increased severalfold by the presence of the migrants. In numerical terms the potential for migrants having a severe impact on resources for local residents certainly exists, but several lines of evidence indicate that possible competition is not strong. Most importantly, a number of local species on the study area regularly continued 
Table 5. Comparisons of migrant and local avifauna with respect to body mass and diet category

MIGRANTS

Winter residents (RR, RV)

All regular migrants in area LOCAL SPECIES

Captured on study area

Regular in UCR area ${ }^{1}$
MIGRANTS

Winter residents (RR, RV)

All regular migrants in area LOCAL SPECIES

Captured on study area

Regular in UCR area ${ }^{1}$

\begin{tabular}{llllllll}
\multicolumn{8}{c}{ Number of species with body mass (gm): } \\
\hline$\leqslant 5$ & $6-12$ & $13-25$ & $26-50$ & $51-100$ & $101-250$ & $251-500$ & 500
\end{tabular}

$\begin{array}{rrrrrrrr}0 & 9 & 9 & 4 & 1 & 0 & 0 & 0 \\ 1 & 28 & 17 & 13 & 3 & 1 & 2 & 1 \\ 2 & 4 & 4 & 9 & 9 & 2 & 0 & 0 \\ 7 & 13 & 15 & 18 & 20 & 11 & 7 & 3\end{array}$

Number of species in diet category:

\begin{tabular}{rcccccc}
\hline $\begin{array}{c}\text { small } \\
\text { insects }\end{array}$ & $\begin{array}{c}\text { large insect/ } \\
\text { small herps }\end{array}$ & $\begin{array}{c}\text { vertebrate } \\
\text { carrion }\end{array}$ & fruit & seeds & nectar & $\Sigma$ \\
19 & 1 & 0 & 2 & 1 & 0 & 23 \\
42 & 3 & 4 & 10 & 3 & 4 & 66 \\
& & & & & & \\
9 & 7 & 7 & 20 & 13 & 7 & 94 \\
35 & 12 & 7 &
\end{tabular}

${ }^{1}$ Includes breeding residènts, regular visitors, seasonal residents (= altitudinal or local migrants); see Stiles (1990).

nesting into September (e.g. Thryothorus, Troglodytes, Melozone, Saltator, Volatinia, Zonotrichia); a number of others regularly had newly fledged young in September-October (e.g. Catharus, Cyclarhis). Most local species also underwent part or all of the annual moult during the migration period. Taken together, these observations indicate that, on the whole, the fall migration period for Nearctic-breeding landbirds was far from being a period of resource scarcity for local resident birds.

\section{Discussion}

Several conclusions regarding fall migration through the Valle Central of Costa Rica may be drawn from this study. First, arrival dates of fall migrants are fairly consistent from year to year; any given species usually arrives within a week or so of the long-term average date. Although I shall not attempt to do so here, it would be interesting to compare the degree of variability in arrival dates in fall migration reported here with that for dates of arrival at breeding grounds or stopover sites in North America during the northbound spring migration.

Another major conclusion is that passage migrants and winter residents differ in several aspects of their migrations through the study area, both within and between species. Passage migrants tend to arrive and pass through earlier in the season; they also have greater fat reserves, and do not show any consistent change in fat reserves through the migratory period. By contrast, species that are winter residents in the area tend to arrive later and have lower fat reserves. Individuals of passage migrant species are virtually never recaptured in succeeding years, whereas an appreciable proportion of individuals of winter resident species are recaptured on the area in one or more years following banding. Site-fidelity is thus fairly pronounced in winter residents but non-existent in passage migrants. 
Interestingly, a number of the differences between passage migrant and winter resident species also occur between early and late-arriving individuals of the latter. Early-arriving individuals tend to be fatter, and to be recaptured less in succeeding years, than those that arrive late. It is thus probable that the individuals that remain on the area for the winter are drawn disproportionately from among those individuals arriving late on the area. Such an arrangement would tend to reduce intraspecific competition for resources in these species, in that resident individuals do not settle until most transients have gone through the area.

In most species, first-year and older birds occur on the area in similar numbers but in several, immatures exceed adults, and in a few the reverse applies. In several species adults pass through before immatures, on average; in no species does the reverse occur. Finally, both at local and regional levels, migrants and local resident species differ in size distributions and diet types, suggesting that these two groups are to some extent complementary in an ecological sense. Breeding among many local residents is ending as the migrants begin to arrive in numbers in September, but many of the former have nestlings, fledglings, or are moulting well into October-November.

On another level, this study demonstrates how, with a relatively small investment of time and energy at any one time, but continued over a long period, and with a relatively low budget (total cost of this study was surely under US\$80o), one can obtain answers to a number of interesting questions regarding migration. It is precisely this "low-key" aspect of the present study that may make it practical to duplicate in other areas of the Neotropics. Another important conclusion derives from the nature of the study area itself: a patch of secondgrowth scrub in no way exceptional, chosen purely for its convenience for the UCR campus.

The fact that we were able to band over 5,00o migrants, and over 6,000 birds overall, on this small area highlights the importance of patches of native vegetation, however degraded, in providing stopover and winter habitat for a variety of migrant species, as well as breeding habitat for native species. In the current controversy over the effects of tropical deforestation on populations of longdistance migrants (e.g. Terborgh 1989), we sometimes overlook the fact that deforestation is only one of the land-use changes detrimental to migrants (and native avifaunas). Other such changes include replacement of shaded traditional coffee plantations with open coffee monocultures; replacement of shaded pastures by extensive open ricefields and other monocultures (see Thurber et al. 1987), or replacement of native vegetation in patches of scrub and vacant lots, by exotic plantings in urban and suburban developments.

All of these changes are occurring rapidly throughout Latin America, and we are far from understanding in detail their effects on the avifauna. As an example, long-term observations in the UCR area have documented population declines of 48 native species in the process of urbanization in the Valle Central of Costa Rica (Stiles 1990). Thus, it is important for more Neotropical ornithologists to take advantage of nearby, easily accessible areas to be able to document in detail avifaunal changes, involving both local residents and migrants, in relation to changes in land use. The resulting database will be of great value in designing practical conservation measures for birds, both local and migratory. 


\section{Acknowledgements}

I am very grateful to the many early-rising students and colleagues who helped carry out this study, especially Nidia Arguedas, Gilbert Barrantes, Rafael Campos, Rolando Delgado, Ana Pereira, Jenny Reynolds, Andrés Román, Loreta Rosselli, Julio Sánchez and Susan Smith. Nidia Arguedas, Gilbert Barrantes, Rolando Delgado, Ana Pereira and Loreta Rosselli helped in the analysis of the data at the Centro de Informática, Universidad de Costa Rica; the analyses were facilitated by funds from the Vicerrectoría de Investigacion, UCR. Finally, I thank the International Council for Bird Preservation (Pan American Section), especially Kimberley Young, and World Wildlife Fund-U.S. for the opportunity to attend this symposium.

Appendix I: Status, arrival date, total number banded, and number and proportion of individuals recaptured in succeeding years, for all migrant birds banded 1976-1988 on UCR Finca study area.

\begin{tabular}{|c|c|c|c|c|c|}
\hline Species & Status & $\begin{array}{l}\text { Arrival } \\
\text { date }^{1}\end{array}$ & $\begin{array}{c}\text { Total } \\
\text { number } \\
\text { banded }\end{array}$ & $\begin{array}{c}\text { Number } \\
\text { recap- } \\
\text { tured }^{2}\end{array}$ & $\begin{array}{c}\text { Proportion } \\
\text { recap- } \\
\text { tured }^{2}\end{array}$ \\
\hline Butorides striatus Green-backed Heron & $\mathrm{P}_{2}-\mathrm{P}_{1}$ & - & $\mathbf{1}$ & o & - \\
\hline Actitis macularia Spotted Sandpiper & RV & - & 2 & o & - \\
\hline Chordeiles acutipennis Lesser Nighthawk & $P_{2}-P_{1}$ & - & $\mathbf{1}$ & $o$ & - \\
\hline Coccyzus americanus Yellow-billed Cuckoo & $\mathrm{P}_{1}-\mathrm{P}_{2}$ & $50-77$ & 7 & 0 & - \\
\hline C. erythrophthalmus Black-billed Cuckoo & $P_{1}$ & $59-81$ & 5 & 0 & - \\
\hline $\begin{array}{l}\text { Archilocus colubris Ruby-throated } \\
\text { Hummingbird }\end{array}$ & $\mathrm{P}_{2}$ & $67-88$ & 12 & 0 & - \\
\hline Tyrannus tyrannus Eastern Kingbird & $P_{1}$ & $52 \pm 12$ & II & o & - \\
\hline $\begin{array}{l}\text { Myiodynastes luteiventris Sulphur-bellied } \\
\text { Flycatcher }\end{array}$ & $P_{1}$ & - & II & o & - \\
\hline Myiarchus crinitus Great Crested Flycatcher & RR & $60 \pm 7$ & 69 & $\mathbf{I}$ & $(0.016)$ \\
\hline Empidonax alnorum Alder Flycatcher & $P_{1}$ & $32 \pm 8$ & 606 & o & - \\
\hline E. trailli Willow Flycatcher & $P_{2, R V ?}$ & - & 251 & o & - \\
\hline E. virescens Acadian Flycatcher & $P_{2}-P_{1}$ & $59-71$ & 36 & o & - \\
\hline E. flaviventris Yellow-bellied Flycatcher & RV & $43 \pm 4$ & 30 & o & - \\
\hline E. minimus Least Flycatcher & $\mathrm{XV}$ & - & 1 & $\circ$ & - \\
\hline Contopus borealis Olive-sided Flycatcher & $P_{1}$ & $44 \pm 7$ & 17 & 0 & - \\
\hline C. virens Eastern Wood Pewee & $P_{1}$ & $32 \pm 10$ & 115 & 0 & - \\
\hline C. sordidulus Western Wood Pewee & $P_{1}$ & - & 115 & o & - \\
\hline Hirundo rustica Barn Swallow & $P_{1}-P_{2}$ & $22 \pm 7$ & 25 & 0 & - \\
\hline Riparia riparia Bank Swallow & P1 & $35 \pm 5$ & 3 & 0 & - \\
\hline Dumetella carolinensis Grey Catbird & $X R$ & $7^{8-103}$ & 3 & $I$ & $(0.333)$ \\
\hline Hylocichla mustelina Wood Thrush & RV & $81 \pm 12$ & 6 & o & - \\
\hline Catharus ustulatus Swainson's Thrush & P1 & $59 \pm 7$ & 351 & 0 & - \\
\hline C. minimus Grey-cheeked Thrush & $P_{1}$ & $55-77$ & 43 & o & - \\
\hline C. fuscescens Veery & $P_{1}$ & - & 3 & 0 & - \\
\hline Vireo olivaceus Red-eyed Vireo & P1 & $43 \pm 7$ & 447 & 0 & - \\
\hline$V$. flavoviridis Yellow-green Vireo & $P_{1}$ & - & 73 & 0 & - \\
\hline$V$. flavifrons Yellow-throated Vireo & RR & $74 \pm 9$ & 17 & 1 & $(0.062)$ \\
\hline V. philadelphicus Philadelphia Vireo & RR & $90 \pm 5$ & 40 & 2 & $(0.053)$ \\
\hline Mniotilta varia Black-and-white Warbler & $\mathrm{RV}-\mathrm{P}_{2}$ & $35 \pm 6$ & 21 & 0 & - \\
\hline Protonotaria citrea Prothonotary Warbler & $P_{2}$ & $50 \pm 5$ & 15 & 0 & - \\
\hline $\begin{array}{l}\text { Helmitheros vermivorus Worm-eating } \\
\text { Warbler }\end{array}$ & $\mathrm{RV}-\mathrm{P}_{2}$ & $5^{8}-55$ & 7 & 0 & - \\
\hline $\begin{array}{l}\text { Vermivora chrysoptera Golden-winged } \\
\text { Warbler }\end{array}$ & $\mathrm{RV}-\mathrm{P}_{2}$ & $57 \pm 8$ & 45 & 1 & $(0.022)$ \\
\hline$V$. pinus Blue-winged Warbler & XV & - & 1 & o & - \\
\hline
\end{tabular}


Appendix 1-continued

\begin{tabular}{|c|c|c|c|c|c|}
\hline Species & Status & $\begin{array}{l}\text { Arrival } \\
\text { date }^{1}\end{array}$ & $\begin{array}{c}\text { Total } \\
\text { number } \\
\text { banded }\end{array}$ & $\begin{array}{c}\text { Number } \\
\text { recap- } \\
\text { tured }^{2}\end{array}$ & $\begin{array}{c}\text { Proportion } \\
\text { recap- } \\
\text { tured }^{2}\end{array}$ \\
\hline$V$. peregrina Tennessee Warbler & $R R$ & $63 \pm 8$ & 897 & 58 & $(0.069)$ \\
\hline Dendroica petechia Yellow Warbler & $\mathrm{P}_{1}-\mathrm{P}_{2}$ & $33 \pm 6$ & 137 & 3 & $(0.022)$ \\
\hline D. magnolia Magnolia Warbler & XV & - & 1 & o & - \\
\hline D. virens Blue-throated Green Warbler & XV & - & $\mathbf{I}$ & o & - \\
\hline D. fusca Blackburnian Warbler & $\mathrm{P}_{1}-\mathrm{P}_{2}, \mathrm{RV}$ & $43 \pm 8$ & 162 & o & - \\
\hline D. cerulea Cerulean Warbler & $\mathrm{XV}$ & - & 3 & o & - \\
\hline D. pensylvanica Chestnut-sided Warbler & RR & $53 \pm 6$ & 136 & 2 & $(0.015)$ \\
\hline D. castanea Bay-breasted Warbler & PI & $76 \pm 7$ & 56 & o & - \\
\hline D. striata Blackpoll Warbler & XV & - & 2 & 0 & - \\
\hline Seiurus aurocapillus Ovenbird & RR & $59 \pm 7$ & 111 & 11 & $(0.106)$ \\
\hline S.noveboracensis Northern Waterthrush & RR & $44 \pm 6$ & 126 & 7 & $(0.059)$ \\
\hline Oporornis formosus Kentucky Warbler & RV & $49 \pm 7$ & 30 & 1 & $(0.033)$ \\
\hline O. philadelphia Mourning Warbler & RR & $45 \pm 8$ & 337 & 17 & $(0.058)$ \\
\hline O. tolmiei MacGillivray's Warbler & RR & $44-73$ & 21 & $\mathbf{I}$ & $(0.056)$ \\
\hline Geothlypis trichas Northern Yellowthroat & $P_{2 ; R V ?}$ & $70-95$ & 18 & o & - \\
\hline Icteria virens Yellow-breasted Chat & $\mathrm{XR}$ & $71-105$ & 4 & 1 & $(0.250)$ \\
\hline Wilsonia citrina Hooded Warbler & $X V$ & - & 3 & o & - \\
\hline W. pusilla Wilson's Warbler & RR & $53 \pm 5$ & 145 & 17 & $(0.130)$ \\
\hline W. canadensis Canada Warbler & P1 & $45 \pm 5$ & 178 & 0 & - \\
\hline Setophaga ruticilla American Redstart & $\mathrm{P}_{2}$ & $30 \pm 8$ & 13 & 0 & - \\
\hline Icterus spurius Orchard Oriole & $\mathrm{P}_{2}$ & $28 \pm 8$ & 113 & 0 & - \\
\hline I. galbula Baltimore Oriole & $\mathrm{RR}$ & $55 \pm 8$ & 83 & 2 & $(0.030)$ \\
\hline Piranga olivacea Scarlet Tanager & $P_{1}$ & $74 \pm 5$ & 17 & o & - \\
\hline P. rubra Summer Tanager & RR & $63 \pm 8$ & 41 & 1 & $(0.026)$ \\
\hline $\begin{array}{l}\text { Pheucticus ludovicianus Rose-breasted } \\
\text { Grosbeak }\end{array}$ & RR & $71 \pm 6$ & 75 & 2 & $(0.030)$ \\
\hline Passerina ciris Painted Bunting & $X V$ & - & 1 & o & - \\
\hline P. cyanea Indigo Bunting & RR & $75 \pm 10$ & 525 & 26 & $(0.052)$ \\
\hline Spiza americana Dickcissel & $P_{1}$ & $46 \pm 7$ & 7 & o & - \\
\hline Guiraca caerulea Blue Grosbeak & XV & - & 2 & o & - \\
\hline Melospiza lincolnii Lincoln's Sparrow & XV & - & 1 & 0 & - \\
\hline
\end{tabular}

${ }^{1}$ For species with reliable arrival dates in to or more years, mean and standard deviation are given; for 5-9 years, range of arrival dates is given; for less than 5 , no dates are given (generally rare or accidental in study area).

${ }^{2}$ Recapture proportions calculated based on numbers banded through 1987.

Appendix 2. Numbers of individuals of local species banded ${ }^{1}$ and recaptured on the study area, $1980-1988$.

\begin{tabular}{lccc}
\hline Species & $\begin{array}{c}\text { Total number } \\
\text { banded }\end{array}$ & $\begin{array}{c}\text { Number } \\
\text { recaptured }\end{array}$ & $\begin{array}{c}\text { Proportion } \\
\text { recaptured }\end{array}$ \\
\hline Leptotila verreauxi White-tipped Dove & 6 & 1 & $(0.167)$ \\
Columbina passerina Common Ground-dove & 4 & 0 & - \\
Scardafella inca Inca Dove & 8 & 1 & $(0.125)$ \\
Piaya cayana Squirrel Cuckoo & 2 & 0 & - \\
Crotophaga sulcirostris Groove-billed Ani & 11 & 2 & $(0.182)$ \\
Nyctidromus albicollis Common Pauraque & 2 & 0 & - \\
Glaucidium brasilianum Ferruginous Pygmy Owl & 14 & 2 & $(0.143)$ \\
Amazilia tzacatl Rufous-tailed Hummingbird & 68 & 18 & $(0.265)$ \\
A. saucerrotei Steely-vented Hummingbird & 44 & 10 & $(0.227)$ \\
Momotus momota Blue-crowned Motmot & 15 & 4 & $(0.267)$ \\
Melanerpes hoffmannii Hoffmann's Woodpecker & 14 & 2 & $(0.143)$
\end{tabular}


Appendix 2-continued

\begin{tabular}{lccc}
\hline Species & $\begin{array}{c}\text { Total number } \\
\text { banded }\end{array}$ & $\begin{array}{c}\text { Number } \\
\text { recaptured }\end{array}$ & $\begin{array}{c}\text { Proportion } \\
\text { recaptured }\end{array}$ \\
\hline Tyrannus melancholicus Tropical Kingbird & 5 & 1 & $(0.200)$ \\
Megarhynchus pitangua Boat-billed Flycatcher & 3 & 0 & \\
Pitangus sulphuratus Great Kiskadee & 5 & 0 & $(0.158)$ \\
Elaenia flavogaster Yellow-bellied Elaenia & 19 & 3 & $(0.107)$ \\
Notiochelidon cyanoleuca Blue-and-white Swallow & 28 & 3 & $(0.286)$ \\
Thryothorus modestus Plain Wren & 98 & 28 & $(0.196)$ \\
Troglodytes aedon House Wren & 56 & 11 & $(0.304)$ \\
Catharus aurantiirostris Orange-billed Nightingale & 46 & 14 & $(0.400)$ \\
Thrush & & & $(0.167)$ \\
Cyclarhis gujanensis Rufous-browed Peppershrike & 10 & 4 & $(0.167)$ \\
Basileuterus rufifrons Rufous-crowned Warbler & 36 & 6 & $(0.133)$ \\
Amblycercus holosericeus Yellow-billed Cacique & 6 & 1 & $(0.167)$ \\
Thraupis episcopus Blue-grey Tanager & 15 & 2 & $(0.273)$ \\
Saltator coerulescens Greyish Saltator & 42 & 7 & $(0.152)$ \\
Atlapetes gutturalis Yellow-throated Brush-finch & 44 & 12 & $(0.111)$ \\
Melozone biarcuatum Prevost's Ground-sparrow & 92 & 14 & $(0.127)$ \\
M. leucotis White-eared Ground-sparrow & 18 & 2 & 91
\end{tabular}

${ }^{1}$ Excluding Zonotrichia capensis (Rufous-collared Sparrow) and Turdus grayi (Clay-coloured Robin).

\section{References}

AOU (1983) Checklist of North American birds. Sixth edition. American Ornithologists' Union.

Hilty, S. L. and Brown, W. L. (1986) A guide to the birds of Colombia. Princeton, New Jersey: Princeton University Press.

Keast, A. and Morton, E. S., eds. (1980) Migrant birds in the Neotropics: ecology, behavior, distribution, and conservation. Washington, D.C.: Smithsonian Institution Press.

Lanyon, W. E. and Bull, J. (1967) Identification of Connecticut, Mourning, and MacGillivray's Warblers. Bird-Banding 38: 187-194.

Lowery, G. H. and Newman, R. J. (1966) A continentwide view of bird migration on four nights in October. Auk 83: 547-586.

Ouellet, H., ed. (1988) Acta XIX Congressus Internationalis Ornithologici. Ottawa: University of Ottawa Press.

Phillips, A. R., Howe, M. A. and Lanyon, W. E. (1966) Identification of the flycatchers of eastern North America, with special emphasis on the genus Empidonax. Bird-Banding 37: 153-171.

Rappole, J. H., Morton, E. S., Lovejoy, T. E. and Ruos, J. R. (1983) Nearctic avian migrants in the Neotropics. Washington, D.C.: U.S. Fish and Wildlife Service.

Ridgely, R. S. (1981) A guide to the birds of Panama. Princeton, New Jersey: Princeton University Press.

Robbins, C. S. (1964) A guide to ageing and sexing of wood warblers (Parulidae) in fall. EBBA News 27: 199-215.

Stiles, F. G. (1983) Birds: introduction. Pp.503-530 in D. H. Janzen, ed. Costa Rican natural history. Chicago: University of Chicago Press.

Stiles, F. G. (1990) La avifauna de la Universidad de Costa Rica y sus alrededores a través de 20 años 1968-1989. Revta. Biol. Tropical 38: 361-381.

Stiles, F. G. and Skutch, A. F. (1989) A guide to the birds of Costa Rica. Ithaca, NY: Cornell University Press. 
Terborgh, J. (1989) Where have all the birds gone? Princeton: Princeton University Press. Thurber, W. A., Serrano, J. F., Sermeño, A. and Benítez, M. (1987) Status of uncommon and previously unreported birds of El Salvador. Proc. Western Found. Vert. Zool. 3: 109293.

Wood, M. S. (1969) A bird bander's guide to determination of age and sex of selected species. Pennsylvania: Pennsylvania State University, University Park.

F. GARY STILES

Instituto de Ciencias Naturales, Universidad Nacional de Colombia, Apartado 7495, Bogotá D.C., Colombia. 